\title{
Modulation of thyroid hormone receptors, TR $\alpha$ and TR $\beta$, by using different doses of triiodothyronine (T3) at different times
}

\author{
Modulação dos receptores de hormônio \\ tireoidiano, TR $\alpha$ e TR $\beta$, utilizando diferentes doses de \\ triiodotironina (T3) em diferentes tempos
}

Miriane de Oliveira', Renata de Azevedo Melo Luvizotto', Regiane Marques Castro Olimpio', Maria Teresa de Sibio', Carolina Biz Rodrigues Silva², Sandro José Conde', Carlos Roberto Padovani ${ }^{3}$, Célia Regina Nogueira'

1 Department of Internal Clinic, Botucatu Medicine School, São Paulo State University (Unesp), Botucatu, SP, Brazil ${ }^{2}$ Department of Physiology, São Paulo Federal University (Unifesp), São Paulo, SP, Brazil ${ }^{3}$ Department of Biostatistics, Biosciences Institute, Unesp, Botucatu, SP, Brazil
Correspondence to: Miriane de Oliveira

Universidade Estadual Paulista Faculdade de Medicina Distrito de Rubião Jr s/n 18618-000 - Botucatu, SP, Brazil miriane.deoliveira@yahoo.com.br

Received on Dec/7/2012 Accepted on Jan/21/2013

\begin{abstract}
Objective: To examine the effect of different doses of triiodothyronine (T3) on mRNA levels of thyroid hormone receptors, TR $\alpha$ and TR $\beta$, at different times. Materials and methods: 3T3-L1 adipocytes were incubated with T3 (physiological dose: F; supraphysiological doses: SI or SII), or without T3 (control, C) for $0.5,1,6$, or $24 \mathrm{~h}$. TR $\alpha$ and TR $\beta$ mRNA was detected using real-time polymerase chain reaction. Results: $F$ increased TR $\beta$ mRNA levels at $0.5 \mathrm{~h}$. After $1 \mathrm{~h}, \mathrm{TR} \alpha$ levels increased with F and SI and TR $\beta$ levels decreased with SII compared with C, F, and SI. After 6h, both genes were suppressed at all concentrations. In 24h, TR $\alpha$ and TR $\beta$ levels were similar to those of $\mathrm{C}$ group. Conclusions: T3 action with $\mathrm{F}$ began at $1 \mathrm{~h}$ for $\operatorname{TR} \alpha$ and at $0.5 \mathrm{~h}$ for TR $\beta$. These results suggest the importance of knowing the times and doses that activate $\mathrm{T} 3$ receptors in adipocytes. Arq Bras Endocrinol Metab. 2013;57(5):368-74
\end{abstract}

Keywords

$\operatorname{TR} \alpha$; TR $\beta$; triiodothyronine; adipocytes

\section{RESUMO}

Objetivo: Examinar o efeito de diferentes doses de triiodotironina (T3) sobre a expressão gênica dos receptores TR $\alpha$ e TR $\beta$ em diferentes tempos. Materiais e métodos: Adipócitos, 3T3-L1, foram incubados com T3 nas doses fisiológica (F, 10nM) e suprafisiológicas (SI, 100nM ou SII, 1000nM) ou veículo (controle, C) durante 0,5, 1, 6 ou 24h. mRNA dos TRs foram detectados utilizando PCR em tempo real. Resultados: Níveis deTR $\beta$ aumentaram em F em 0,5h. Após $1 \mathrm{~h}$, níveis de TR $\alpha$ aumentaram em F e SI comparado ao $\mathrm{C}$, enquanto TR $\beta$ diminuiu no SIl comparado com C, F, e SI. Após 6h, ambos os genes foram suprimidos em todas concentrações. Em 24h, níveis de TR $\alpha$ e TR $\beta$ retornaram aos do C. Conclusões: Ação do T3 em F iniciou-se em 1h para $\operatorname{TR} \alpha$ e 0,5h paraTR $\beta$. Esses resultados são importantes para determinar tempo inicial e dose de T3 em que os receptores de HT são ativados em adipócitos. Arq Bras Endocrinol Metab. 2013;57(5):368-74

\section{Descritores}

TR $\alpha$; TR $\beta$; triiodotironina; adipócitos

\section{INTRODUCTION}

$\mathrm{T}$ hyroid hormones $(\mathrm{TH})$ influence the metabolism and development of adipose tissue by modulating the proliferation and differentiation of adipocytes (1).
$\mathrm{TH}$ action is mediated mainly by the modification of gene expression by nuclear receptors, which are transcriptional factors regulated by ligands that adhere to the chromatin (2). TH receptors (TR) are proteins that 
belong to the nuclear hormone receptor superfamily. These receptors originate from the genes for TR alpha $(T R \alpha)$ and TR beta $(T R \beta)(3,4)$ that, in humans, are located on chromosomes 17 and 3 , respectively.

According to Yen (5) and Obregon (6), adipose tissue represents an important target for $\mathrm{TH}$ because it expresses TR $\alpha$ and TR $\beta$. THs are regarded as important factors in the regulation of the development and function of adipose tissue $(5,7,8)$. It has been shown that TRs are expressed in both white and brown adipose tissue. However, there have been no studies on the modulation of TRs by different doses of triiodothyronine (T3) at different times.

In this study, we evaluated the effects of different doses and times of T3 on the expression levels of TRs. We observed that TR $\beta$ was modulated by T3 starting at $0.5 \mathrm{~h}$, and $\mathrm{TR} \alpha$ was modulated later, starting at $\mathrm{lh}$.

\section{MATERIALS AND METHODS}

\section{Cell culture and differentiation}

The experimental protocol was approved by the Ethics Committee on Animal Experiments of the Botucatu School of Medicine-UNESP (protocol $\mathrm{n}^{\circ} 752$ ).

For the in vitro study, the 3T3-Ll cell line was used. These cells were acquired from the Cell Bank of the Rio de Janeiro Federal University (UFRJ) and were cultured in Dulbecco's Modified Eagle's Medium (DMEM) $\left(\right.$ Gibco $^{\circledR}$, Life Technologies Corporation, Grand Island, NY, USA) was supplemented with $10 \%$ fetal bovine serum (FBS) (Gibco ${ }^{\circledR}$, Life Technologies Corporation), $1 \%$ antibiotic/antimycotic (Sigma-Aldrich Co. LLC, St. Louis, MO, USA) agent, under an atmosphere of $5 \% \mathrm{CO}_{2}$ at $37^{\circ} \mathrm{C}$. Cells were maintained in these culture conditions until they reached approximately $100 \%$ confluency, and were subsequently transferred to 6-well plates. After reaching $100 \%$ confluency in the wells, cells were submitted to the differentiation process, during which they remained for 3 days in DMEM containing 10\% FBS, $100 \mathrm{mM}$ 1-methyl-3-isobutilxanthine (IBMX) (Sigma-Aldrich Co. LLC), $1 \mathrm{mM}$ dexamethasone (Sigma-Aldrich Co. LLC), and $5 \mathrm{mg} / \mathrm{L}$ insulin (Sigma-Aldrich Co. LLC). After this period, cells were maintained for 7 days in DMEM containing 10\% FBS and $5 \mathrm{mg} / \mathrm{mL}$ insulin. Following the period of cell differentiation, adipocytes were subjected to $\mathrm{TH}$ depletion for $36 \mathrm{~h}$ in DMEM supplemented with charcoal-stripped fetal serum (Sigma-Aldrich Co. LLC).
Subsequently, cells were treated with a physiological dose of T3 (10 nM, which is hereafter referred to as F) or supraphysiological doses of T3 (100 nM and 1000 $\mathrm{nM}$, which are hereafter called SI and SII, respectively) for $0.5,1,6$, or $24 \mathrm{~h}$. A non-treated group, only $0.1 \%$ $\mathrm{NaOH}$ (diluent T3), was used as control (C).

\section{Oil red 0 staining}

After 10 days of differentiation, the culture medium was removed, and the cells were washed twice with phosphate-buffered saline. Subsequently, $1 \mathrm{~mL}$ of formaldehyde was added, and the cells were incubated for $30 \mathrm{~min}$ at room temperature, and then washed 3 times with phosphate-buffered saline. Thereafter, $300 \mu \mathrm{L}$ of Oil Red O dye (Sigma-Aldrich Co. LLC) was added, and the cells were incubated for $2 \mathrm{~h}$ at $37^{\circ} \mathrm{C}$. After that period, cells were washed 3 times with distilled water and placed in an incubator to dry. Cells were observed under a microscope in order to verify differentiation by red coloring of the adipose cells.

\section{Gene expression}

Total RNA was extracted from the 3T3-Ll cells with the TRIzol reagent (Life Technologies Corporation) according to the manufacturer's instructions. The High Capacity cDNA Reverse Transcription Kit for RT-PCR ${ }^{\circledR}$ (Life Technologies Corporation) was used to synthesize $20 \mu \mathrm{L}$ of cDNA from 1000 ng of total RNA.

TR $\alpha$ and TR $\beta$ mRNA levels (Table 1) were determined by real-time polymerase chain reactions (RT-qP$\mathrm{CR}$ ). Quantitative measurements were performed with Applied Biosystems StepOne Plus detection system with the TaqMan qPCR commercial kit (Life Technologies Corporation) according to the manufacturer's instructions. The amplification conditions were as follows: enzyme activation at $50^{\circ} \mathrm{C}$ for $2 \mathrm{~min}$, denaturation at $95^{\circ} \mathrm{C}$ for $10 \mathrm{~min}$. The cDNA products were amplified by 40 cycles of denaturation at $95^{\circ} \mathrm{C}$ for $15 \mathrm{~s}$, and annealing/extension at $60^{\circ} \mathrm{C}$ for $1 \mathrm{~min}$. All assays were performed in triplicate. Levels of gene expression

Table 1. Assays used at RT-qPCR

\begin{tabular}{lc}
\hline Gene & Assay \\
\hline TR $\beta$ & Mm00437044_m1 \\
TR $\alpha$ & Mm00617505_m1 \\
Cyclophilin & Mm00434759_m1 \\
\hline
\end{tabular}

TRß: thyroid hormone receptor beta; TR $\alpha$ : thyroid hormone receptor alpha. TR $\beta$ and TR $\alpha$ assays correspond to homologue sequence of isoforms 1 and 2 . 
were quantified relative to group $\mathrm{C}$ value, after normalization with the internal control (cyclophilin) by the $2^{-\Delta \Delta \mathrm{Ct}}$ method, as described elsewhere (9).

\section{Statistical analysis}

The differences between TR $\alpha$ and TR $\beta$ mRNA levels for all experiments were assessed by Student's $t$ -test. Differences of TR $\alpha$ and TR $\beta$ gene expression for different $\mathrm{T} 3$ doses at each moment were assessed by one-way analyses of variance (ANOVA) followed by Tukey's test. Data are expressed as mean \pm standard deviation. Significance level was set at $5 \%$.

\section{RESULTS}

Figure 1A shows 3T3-Ll cells prior to differentiation. In the presence of the differentiation cocktail (insulin, dexamethasone, and IBMX), cells differentiated from preadipocytes into adipocytes that had the morphology of mature adipocytes, characterized by a large quantity of lipid droplets in the cytoplasm (Figures IB and C). These droplets become more evident with the oil red staining (Figure 1C), as the lipids get stained in red.

\section{Differential expression of $\operatorname{TR} \alpha$ and $\operatorname{TR} \beta$ in adipocytes}

Data obtained in the current study show differential expression of TR $\alpha$ and TR $\beta$ levels in adipocytes. TR $\alpha$ expression levels were higher in comparison with TR $\beta$ for all groups (Table 2).

\section{Different concentrations of T3 modulated TR $\alpha$ mRNA levels at different time periods}

Figure 2 shows the modulation of TR $\alpha$ mRNA levels in the $3 \mathrm{~T} 3-\mathrm{Ll}$ adipocytes in the absence (C group) or presence of T3 (F, SI, and SII groups) at different mo- ments $(0.5,1,6$, or $24 \mathrm{~h})$, as measured by RT-qPCR . The different concentrations of $\mathrm{T} 3 \mathrm{did}$ not affect the levels of mRNA expression of the TR $\alpha$ gene in the 0.5$\mathrm{h}$ treatment period (Figure 2A). TR $\alpha$ expression levels were higher at $\mathrm{lh}$ of treatment in the SI and $\mathrm{F}$ groups in comparison with the C and SII groups (Figure 2B). At the 6-h time point, TR $\alpha$ gene expression levels decreased in groups F, SI, and SII in comparison with group $\mathrm{C}$ (Figure 2C). TR $\alpha$ levels were increased in treatment group F at 24 h compared with C. However, there was a decrease in the SI and SII groups in comparison with the increase that was observed in $\mathrm{F}$ (Figure 2D).

Table 2. Differential expression of TR $\beta$ and TR $\alpha$ mRNA levels

\begin{tabular}{ccccc}
\hline & Group & TR $\beta$ & TR $\alpha$ & p \\
\hline \multirow{6}{*}{$0.5 \mathrm{~h}$} & C & $1.00 \pm 0.24$ & $231.00 \pm 68.22$ & $<0.001$ \\
& F & $2.63 \pm 0.5$ & $373.00 \pm 75.52$ & $=0.001$ \\
& SI & $1.89 \pm 0.24$ & $323.59 \pm 53.55$ & $<0.001$ \\
& SII & $1.88 \pm 0.39$ & $279.10 \pm 54.80$ & $<0.001$ \\
& C & $1.00 \pm 0.18$ & $82.15 \pm 7.01$ & $<0.001$ \\
& F & $1.10 \pm 0.04$ & $146.45 \pm 17.29$ & $<0.001$ \\
& SI & $0.99 \pm 0.11$ & $176.11 \pm 35.87$ & $=0.001$ \\
& SII & $0.42 \pm 0.02$ & $70.73 \pm 10.40$ & $<0.001$ \\
& C & $1.00 \pm 0.19$ & $169.87 \pm 17.79$ & $<0.001$ \\
& F & $0.22 \pm 0.03$ & $69.89 \pm 7.98$ & $=0.001$ \\
& SI & $0.14 \pm 0.003$ & $34.93 \pm 1.97$ & $<0.001$ \\
& SII & $0.04 \pm 0.002$ & $5.73 \pm 0.31$ & $<0.001$ \\
& C & $1.00 \pm 0.14$ & $179.74 \pm 44.72$ & $=0.002$ \\
& F & $0.76 \pm 0.01$ & $298.18 \pm 12.69$ & $<0.001$ \\
& SI & $0.81 \pm 0.04$ & $201.82 \pm 0.31$ & $<0.001$ \\
& SII & $0.79 \pm 0.01$ & $131.73 \pm 17.4$ & $<0.001$ \\
\hline
\end{tabular}

3Т3-L1 adipocytes were treated with $\mathrm{T} 3$ at physiological dose $(F, 10 \mathrm{nM})$ and supraphysiological doses (Sl, $100 \mathrm{nM}$ or Sll, $1000 \mathrm{nM}$ ) or without T3 (C, control) for $0.5 \mathrm{~h}, 1 \mathrm{~h}, 6 \mathrm{~h}$, or 24h. Total RNA was extracted and analyzed by RT-qPCR. Data are expressed as means \pm standard deviations. Comparison between TR $\beta$ and TR $\alpha$ mRNA levels were analyzed using Student's $t$ test. All assays were performed in triplicate ( $n=3$ for each treatment).
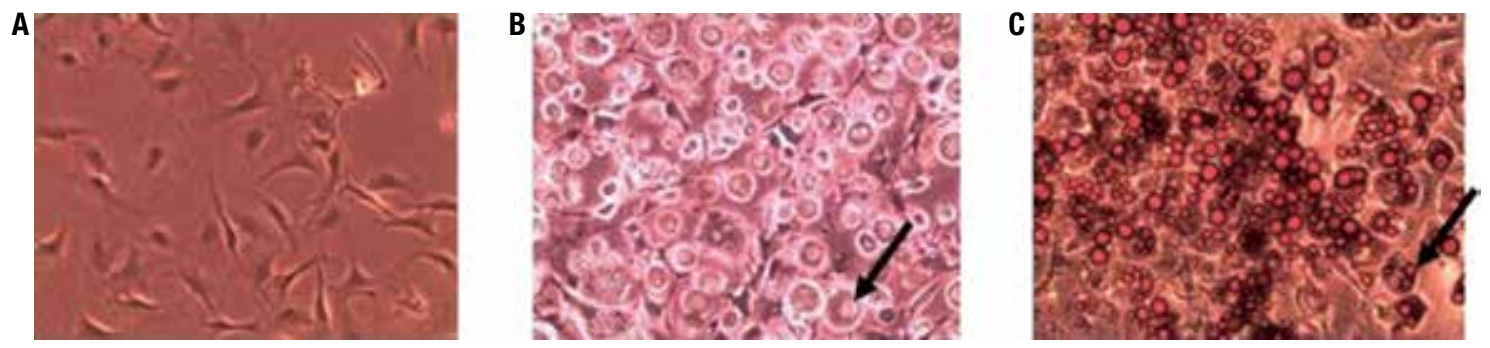

Figure 1. 3T3-L1 cells. (A) Undifferentiated cells. (B) Cells after 10 days of differentiation. (C) Cells stained with oil red after 10 days of differentiation. The arrows indicate an adipocyte with lipid droplets in the cytoplasm. 
A
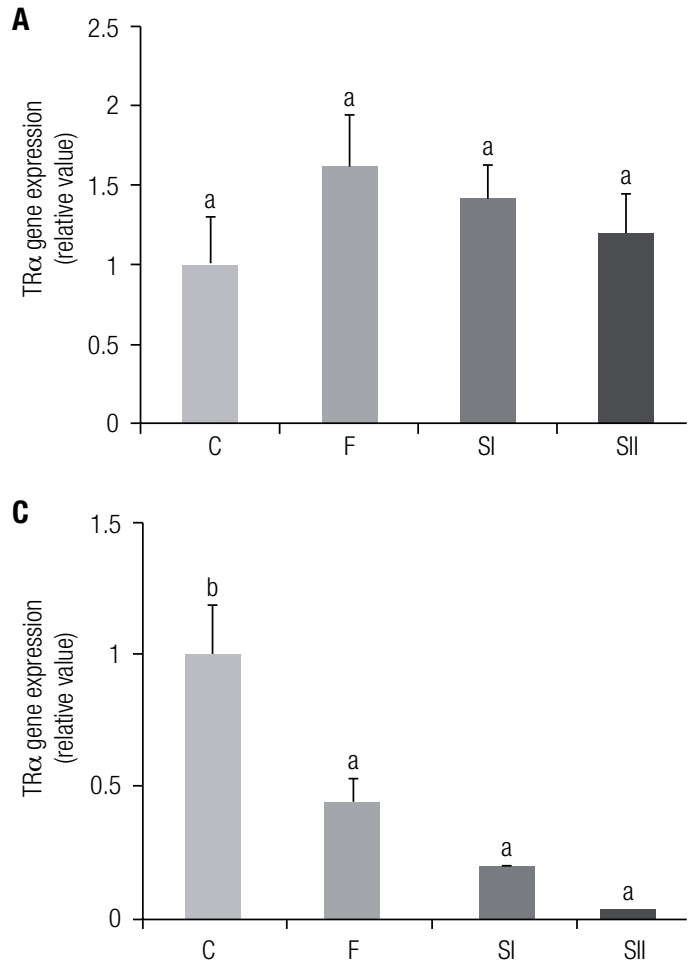

B

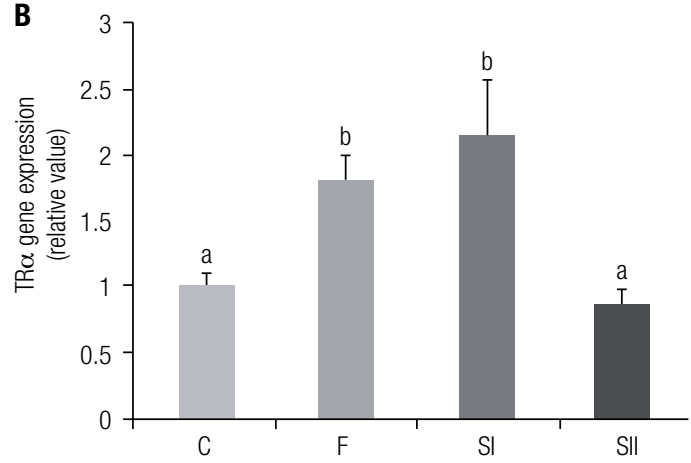

D

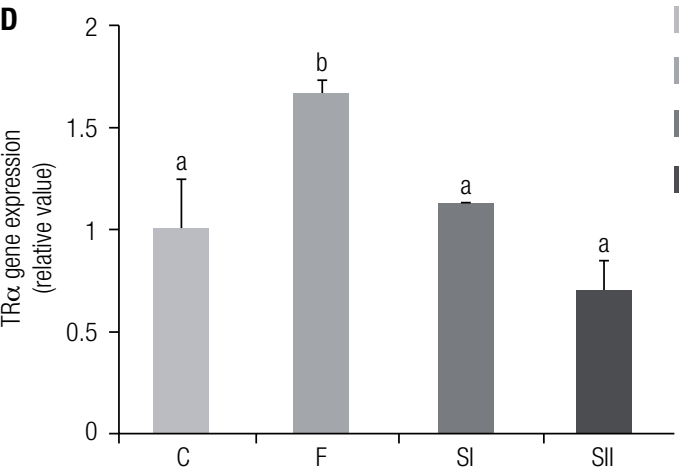

Control $(\mathrm{C})$

10 nM T3 (F)

$100 \mathrm{nM}$ T3 (SI)

1000 nMT3 (SII)

Figure 2. Dose-dependent response for the effects of T3 on TR $\alpha$ mRNA levels at different incubation times. The 3T3-L1 adipocytes were treated with T3 at physiological dose (F, $10 \mathrm{nM})$ or supraphysiological doses (SI, $100 \mathrm{nM}$ or SIl, 1,000 nM), or without T3 (C, control) for 0.5h, 1h, 6h, or 24h. Total RNA was extracted and analyzed by RT-qPCR. (A) Effects of T3 doses on TR $\alpha$ mRNA levels at 0.5h. (B) Effects of T3 doses on TR $\alpha$ mRNA levels at 1h. (C) Effects of T3 doses on TR $\alpha$ mRNA levels at $6 \mathrm{~h}$. (D) Effects of T3 doses on TR $\alpha$ mRNA levels at 24h. Data are expressed as means \pm standard deviations. Data were analyzed using one-way ANOVA complemented with Tukey's test. Similar letters indicate that there was no statistical difference, and different letters indicate that there was a statistical deference at $p<0.05$. Assays were performed in triplicate $(n=3$ for each treatment).

\section{Different concentrations of T3 modulated TR $\beta$ mRNA levels at different time periods}

Figure 3 shows the modulation of TR $\beta$ mRNA levels in the $3 \mathrm{~T} 3-\mathrm{Ll}$ adipocytes in the absence (C group) or presence of T3 (F, SI, and SII groups) at different periods $(0.5,1,6$, or $24 \mathrm{~h})$, as measured by RT-qPCR. There was an increase in TR $\beta$ mRNA levels in F group when compared with those of $\mathrm{C}$, at $0.5 \mathrm{~h}$ (Figure $3 \mathrm{~A}$ ). At $\mathrm{lh}$, suppression in the levels of TR $\beta$ gene expression was evident in SII compared with those of groups C, $\mathrm{F}$, and SI (Figure 3B). At 6h, decrease in TR $\beta$ mRNA levels was observed in groups F, SI, and SII compared with those of group C (Figure 3C). At 24h, TR $\beta$ levels decreased in $\mathrm{F}$ group when compared with $\mathrm{C}$ (Figure 3D).

\section{DISCUSSION}

Lipid metabolism is closely associated with a number of health problems; the regulation of adipocytes re- presents an emerging area of interest. The adipose tissue, which is a target of $\mathrm{TH}$, shows the expression of thyroid receptors that are considered important factors in the regulation of the development and function of this tissue $(5,7,8)$.

The present study was designed to elucidate the effects of T3 on TR $\alpha$ and TR $\beta$ mRNA expression levels in adipose tissue, without the interference of systemic factors. As experimental models, we used the 3T3-Ll cell line, embryonic cells from Mus musculus (Figure 1A), and differentiated in vitro adipocytes (Figures $1 \mathrm{~B}$ and C) because they represent well-established models for adipogenesis (10). Furthermore, we quantified TR $\alpha$ and TR $\beta$ mRNA levels by RT-qPCR.

The TR $\alpha$ gene is widely expressed in the early stages of development, while the TR $\beta$ gene is restricted to the late stages of embryogenesis when it is induced in the brain, pituitary gland, and other tissues (11). We observed that TR $\alpha$ mRNA levels were much higher than TR $\beta$ mRNA levels in 3T3-Ll adipocytes (Table 2), in 


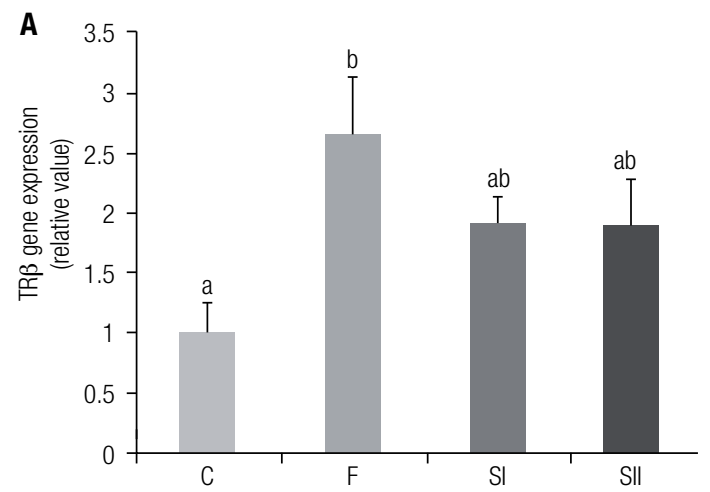

C

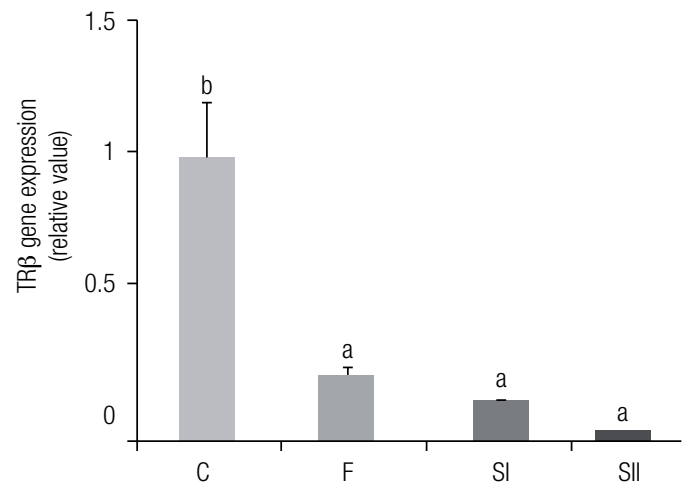

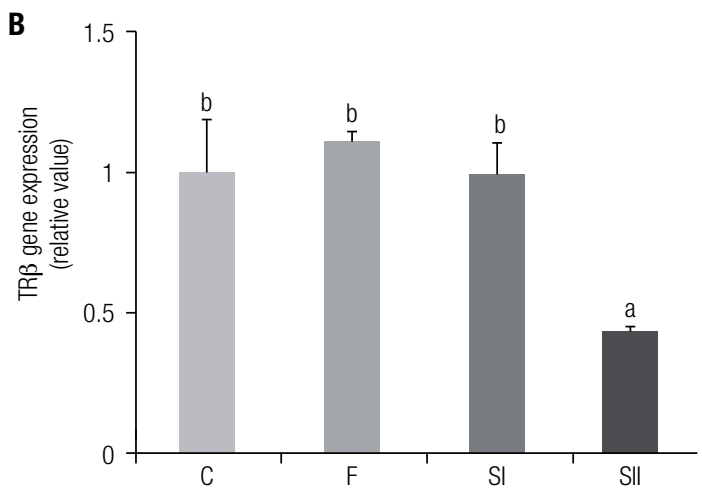

D

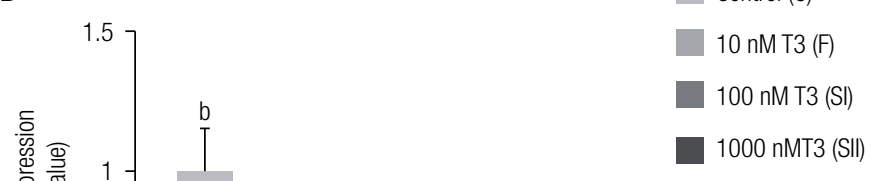

Figure 3. Dose-dependent response for the effects of T3 on TR $\beta$ mRNA levels at different incubation times. The 3T3-L1 adipocytes were treated with T3 at physiological dose (F, $10 \mathrm{nM})$ or supraphysiological doses (SI, $100 \mathrm{nM}$ or SIl, 1,000 nM), or without T3 (C, control) for 0.5h, 1h, 6h, or 24h. Total RNA was extracted and analyzed by RT-qPCR. (A) Effects of T3 doses on TR $\beta$ mRNA levels at 0.5h. (B) Effects of T3 doses on TR $\beta$ mRNA levels at $1 \mathrm{~h}$. (C) Effects of T3 doses on TR $\beta$ mRNA levels at $6 \mathrm{~h}$. (D) Effects of T3 doses on TR $\beta$ mRNA levels at 24h. Data are expressed as means \pm standard deviations. Data were analyzed using one-way ANOVA complemented with Tukey's test. Similar letters indicate that there was no statistical difference, and different letters indicate that there was a statistical deference of $p<0.05$. Assays were performed in triplicate $(n=3$ for each treatment).

agreement with other authors (12). The differential expression of TR genes suggests that they may mediate distinct functions (13). It has been shown that TR $\alpha 1$ is critical in thermoregulation via regulation at the level of local, via central regulation, or both, whereas $\operatorname{TR} \beta$ seems to be more involved in the regulation of lipid metabolic pathways (14). Moreover, although TR $\alpha$ and $\operatorname{TR} \beta$ are similar in the DNA and ligand domains (15), there are fundamental differences in the ligandbinding domain that, nowadays, have enabled the design of ligands that specifically interact with TR $\alpha$ or TR $\beta$, and these have been important tools of isoformspecific actions (16).

We observed that the modulation of the levels of TR $\alpha$ by different doses of T3 was initiated after lh of treatment when the physiological dose of $10 \mathrm{nM}$ (17) that was given to group $\mathrm{F}$ increased the levels of TR $\alpha$ compared with those of groups C and SI. The TR $\alpha$ expression levels in the SII group remained unchanged compared with group C (Figure 2A). We can speculate that this consistency in the TR $\alpha$ expression levels in the SII group was due to a downregulation of this receptor because this group showed a decrease in TR $\alpha$ levels compared with groups F and SI. The downregulation process occurred due to the exposure of the cells to high doses of TH (18).

Monden and cols. (19) observed a decrease in TR $\alpha$ mRNA levels in human medulloblastoma cells (HTB185) at a dose of $100 \mathrm{nM}$, which was the same dose used in the SI group for $24 \mathrm{~h}$. In the present study, we also observed a reduction in TR $\alpha$ in this group compared with the T3 physiological levels that were administrated to group F. However, group F had increased TR $\alpha$ levels compared with group C, and group SII was decreased relative to $\mathrm{F}$ (Figure 2D).

Kanamori e Brown (20) showed that T3 modulated the TR $\alpha$ mRNA expression levels in tadpoles, but it had no effect on the epithelial cell culture of embryonic Xenopus laevis (XL-177) incubated with T3 for 24h at a concentration of $5 \mathrm{nM}$. These findings do not cor- 
roborate our results, which may be due to the use of a different experimental model and of a T3 dose that was lower than that used in our experiments.

Jiang and cols. (12) analyzed the TR $\alpha$ expression levels during the differentiation period of $3 \mathrm{~T} 3-\mathrm{Ll}$ cells in the absence or presence of $\mathrm{T} 3$ at a concentration of $100 \mathrm{nM}$. Although the treated group had a higher accumulation of triglycerides, the TR $\alpha$ expression levels were similar for both treated and untreated cells, different from our results, and probably because mRNA quantification by semi-quantitative PCR is less sensitive than that done with RT-qPCR.

We observed an increase in TR $\beta$ mRNA levels in group $\mathrm{F}$ after 0.5 -h incubation, but not for TR $\alpha$ (Figure $3 \mathrm{~A})$. This led us to speculate that at $0.5 \mathrm{~h}, \mathrm{~T} 3$ bound to its receptor $\alpha$, which is more abundant in adipocytes, resulting in an increased transcription of TR $\beta$. After the l-h incubation, we observed a decrease in TR $\beta$ levels in group SII relative to the other groups (Figure 3B), which indicated a decrease of thyroid receptors in the presence of high doses of T3.

Increasing the incubation period to $6 \mathrm{~h}$, we observed a suppression of TR $\beta$ in the F, SI, and SII groups compared with those in the $\mathrm{C}$ group, which was the same observed for TR $\alpha$ (Figures 3C and 2C). If the transcription of TR $\beta$ depends on the binding of T3 to $\operatorname{TR} \alpha$, that would explain the decreased levels of TR $\beta$ at this incubation time.

At $24 \mathrm{~h}$, only the $\mathrm{F}$ group maintained TR $\beta$ levels below group $\mathrm{C}$ (Figure 3D). There was an increase in the expression of TR $\beta$ at $0.5 \mathrm{~h}$, which was followed by a progressive reduction until $6 \mathrm{~h}$; TR $\beta$ levels tended to return to normality in $24 \mathrm{~h}$. This suggested that a defense or adaptation mechanism occurred in the cells in response to treatment with $\mathrm{TH}$.

Previous studies from our group have shown that physiological doses of T3 decreased TR $\beta$ gene expression levels in the adipose tissue of obese animals that were subjected to food restriction (21), corroborating the results obtained in the present study at 6 and $24 \mathrm{~h}$. Moreover, Liu and cols. (22) found that TR $\beta$ gene expression levels remain unchanged in the myocardium of hyperthyroid rats compared with the myocardium of euthyroid rats, suggesting that the actions of $\mathrm{T} 3$ in its receptors are different for different tissues and experimental models.

In summary, the physiological and supraphysiological doses of T3 modulated TR mRNA expression levels by showing that, at $6 \mathrm{~h}$, a suppression of both genes occurred in the presence of different doses of T3, and that, after $24 \mathrm{~h}$, the expression levels tended to return to normality. Since the interaction with the T3 nuclear receptors leads to the activation or inhibition of target expression of genes, implying the stimulation or blocking of the synthesis of specific proteins, mechanism by which $\mathrm{TH}$ exerts its biological effects on cells, the results presented are important for an understanding in which T3 dose (physiological or supraphysiological), at different incubation times, T3 activates thyroid hormone receptors in adipocytes.

Acknowledgements: we are grateful to Sueli A. Clara, José C. Georgete, Mário B. Bruno, and Keize Nagamati Junior for their technical support. We also would like to thank Editage for the translation of the manuscript into English. Capes and Fapesp (\# 2010/16911-4) provided us with financial support.

Disclosure: no potential conflict of interest relevant to this article was reported.

\section{REFERENCES}

1. Darimont C, Gaillard D, Ailhaud G, Negrel R. Terminal differentiation of mouse preadipocyte cells: adipogenic and antimitogenic role of triiodothyronine. Mol Cell Endocrinol. 1993;98(1):67-73.

2. Cheng SY, Leonard JL, Davis PJ. Molecular aspects of thyroid hormone actions. Endocrin Rev. 2010;31(2):139-70.

3. Williams GR. Cloning and characterization of two novel thyroid hormone receptor beta isoforms. Mol Cell Biol. 2000;20(22):8329-42.

4. Macchia PE, Takeuchi Y, Kawai T, Cua K, Gauthier K, Chassande $\mathrm{O}$, et al. Increased sensitivity to thyroid hormone in mice with complete deficiency of thyroid hormone receptor alpha. Proc Natl Acad Sci USA. 2001;98(1):349-54.

5. Yen PM. Physiological and molecular basis of thyroid hormone action. Physiol Rev. 2001;81(3):1097-142.

6. Obregon MJ. Thyroid hormone and adipocyte differentiation. Thyroid. 2008;18(2):185-95.

7. Flores-Delgado G, Marsch-Moreno M, Kuri-Harcuch W. Thyroid hormone stimulates adipocyte differentiation of 3T3 cells. Mol Cell Biochem. 1987;76(1):35-43.

8. Chawla A, Lazar MA. Induction of Rev-ErbA alpha, an orphan receptor encoded on the opposite strand of the alpha-thyroid hormone receptor gene, during adipocyte differentiation. J Biol Chem. 1993;268(22):16265-9.

9. Livak KJ, Schmittgen TD. Analysis of relative gene expression data using real-time quantitative PCR and the 2(-Delta Delta $C(T)$ ) Method. Methods. 2001;25(4):402-8.

10. Green $H$, Meuth M. An established pre-adipose cell line and its differentiation in culture. Cell. 1974;3(2):127-33.

11. Bradley DJ, Towle HC, Young WS, 3rd. Spatial and temporal expression of alpha- and beta-thyroid hormone receptor mRNAs, including the beta 2-subtype, in the developing mammalian nervous system. J Neurosci. 1992;12(6):2288-302.

12. Jiang W, Miyamoto T, Kakizawa T, Sakuma T, Nishio S, Takeda $T$, et al. Expression of thyroid hormone receptor alpha in 3T3L1 adipocytes; triiodothyronine increases the expression of lipogenic enzyme and triglyceride accumulation. J Endocrinol. 2004;182(2):295-302. 
13. Forrest D, Hanebuth E, Smeyne RJ, Everds N, Stewart CL, Wehner $J M$, et al. Recessive resistance to thyroid hormone in mice lacking thyroid hormone receptor beta: evidence for tissue-specific modulation of receptor function. EMBO J. 1996;15(12):3006-15.

14. Zhu $X$, Cheng SY. New insights into regulation of lipid metabolism by thyroid hormone. Curr Opin Endocrinol Diabetes Obes. 2010;17(5):408-13.

15. Liu YY, Schultz JJ, Brent GA. A thyroid hormone receptor alpha gene mutation $(\mathrm{P} 398 \mathrm{H})$ is associated with visceral adiposity and impaired catecholamine-stimulated lipolysis in mice. J Biol Chem. 2003;278(40):38913-20.

16. Figueira AC, Saidemberg DM, Souza PC, Martinez L, Scanlan TS, Baxter JD, et al. Analysis of agonist and antagonist effects on thyroid hormone receptor conformation by hydrogen/deuterium exchange. Mol Endocrinol. 2011;25(1):15-31.

17. Yoshida T, Monkawa T, Hayashi M, Saruta T. Regulation of expression of leptin mRNA and secretion of leptin by thyroid hormone in 3T3-L1 adipocytes. Biochem Biophys Res Comm. 1997;232(3):822-6.
18. Franklyn JA, Ramsden DB, Sheppard MC. Down-regulation of nuclearT3 receptors by thyroid hormones in the rat anterior pituitary. Mol Cell Endocrinol. 1985;40(2-3):145-8.

19. Monden T, Nakajima Y, Hashida T, Ishii S, Tomaru T, Shibusawa N, et al. Expression of thyroid hormone receptor isoforms downregulated by thyroid hormone in human medulloblastoma cells. Endocr J. 2006;53(2):181-7.

20. Kanamori A, Brown DD. The regulation of thyroid hormone receptor beta genes by thyroid hormone in Xenopus laevis. J Biol Chem. 1992; 267(2):739-45.

21. Luvizotto RA, Conde SJ, Sibio MT, Nascimento AF, Lima-Leopoldo $A P$, Leopoldo AS, et al. Administration of physiologic levels of triiodothyronine increases leptin expression in calorie-restricted obese rats, but does not influence weight loss. Metabolism. 2010;59(1):1-6.

22. Liu CR, Li LY, Shi F, Zang XY, Liu YM, Sun Y, et al. Effects of hyper- and hypothyroid on expression of thyroid hormone receptor mRNA in rat myocardium. J Endocrinol. 2007;195(3):429-38. 